\title{
УUCTEUTBO3HABCTBO
}

УДК 7.04

DOI https://doi.org/10.24919/2308-4863/34-2-1

\author{
Наталія ДАЦЮК, \\ orcid.org/0000-0003-2548-3638 \\ аспірант кафедри дизайну і теорї мистеитва \\ Прикарпатського наиіонального університету імені Василя Стефаника \\ (Івано-Франківськ, Украӥна), \\ асистент кафедри образотворчого мистеитва, \\ дизайну та методики їх навчання \\ Тернопільського національного педагогічного університету \\ імені Володимира Гнатюка \\ (Тернопіль, Україна) nat.datsyuk@gmail.com
}

\section{СТАНОВЛЕННЯ САКРАЛЬНОГО МИСТЕЦТВА СХІДНОЇ ГАЛИЧИНИ КІНЦЯ ХІХ - ПОЧАТКУ ХХ СТОЛІТТЯ НА ПРИКЛАДІ ЦЕРКВИ ВОЗНЕСІННЯ ГОСПОДНЬОГО В СЕЛІ НАСТАСІВ НА ТЕРНОПІЛЬЩИНІ}

\begin{abstract}
У статті розглянуто процес становлення та розвитку сакрального монументального живопису в контексті творення украӥнського національного стилю на теренах Східної Галичини у період між 1900-1940 роками; проаналізовано творчість авторів сакрального мистецтва в середовищі храмів сучасної Тернопільської області на прикладі иеркви Вознесіння Господнього в селі Настасів.

Встановлено, щцо кінець ХІХ століття у Східній Галичині був складним для мистецького життя. Політична ситуація, яка склалася напередодні та під час Першої світової війни, спонукала украйнську інтелігенцію до роздумів про важливість національних традииій і потребу віри. Важливим було виявлення проблем становлення та формування національного українського мистецького стилю в іконописі періоду 1900-1940-х років. Загалом мистецьке життя на теренах Тернопільщини кіния XIX-початку XX століття - малодосліджене явище.

Церква на території Західної України завжди була місцем загального збору громади, тому великого значення надавали оздобленню храму. Наприкінці ХІХ - на початку ХХ століття в архітектурі панував стиль модерн, який сформувався в Свропі у 1880-ті роки. 3 урахуванням того, щчо тогочасна Галичина входила до складу АвстроУгорщини, саме австрійська сеиесія була найближчою для досліджуваного регіону і стала основою для творення украӥнського національного стилю.

Іконографія українських монументальних стінописів на прикладі иеркви в селі Настасів початку XX століття тяжіє до відродження національної традииї. Такі митиі як Дам'ян Горняткевич, Андрій Наконечний, Михайло Зорій, Андрій Лепкий і Северин Борачок ставили за мету поєднання індивідуального стилю із традиціийною структурою та змістовим наповненням поліхромії, пробудження національної самоідентифікаџї серед населення та підвищення рівня його культури. Кожен зі згаданих митиів намагався вирішити поставлені часом завдання по-своєму, але обирав шлях вислову з огляду на власне бачення сучасності, дотримуючись традииії.
\end{abstract}

Ключові слова: сакральне мистецтво, ікона, стінопис, національні традииії.

\author{
Nataliia DATSIUK, \\ orcid.org/0000-0003-2548-3638 \\ Graduate Student at the Department of Design and Art Theory \\ Vasyl Stefanyk Precarpathian National University \\ (Ivano-Frankivsk, Ukraine), \\ Assistant at the Department of Fine Arts, Design and Methods of Their Training \\ Ternopil Volodymyr Hnatiuk National Pedagogical University \\ (Ternopil, Ukraine) nat.datsyuk@gmail.com
}

\section{ESTABLISHMENT OF THE SACRED ART OF EASTERN GALICIA IN THE END OF XIX - EARLY XX CENTURY ON THE EXAMPLE OF THE CHURCH VOZNESINNYA KHRYSTOVOGO IN THE VILLAGE NASTASIV IN TERNOPIL REGION}

The article considers the process of formation and development of sacred monumental painting in the context of the creation of the Ukrainian national style in Eastern Galicia in the period between 1900-1940. The work of authors of the sacred art of churches in the Ternopil region is analyzed on the example of the Church of the Ascension in the village Nastasiv. 
It is established that the end of the XIX century in Eastern Galicia was hard for an artistic life. The political situation on the eve of and during the First World War prompted the Ukrainian intelligentsia to reflect on the importance of national traditions and the need for faith. It is important to identify the problems of formation and formation of the national Ukrainian artistic style in icon painting of the period 1900-1940. At the same time, artistic life in the Ternopil region of the late XIX-early XX century - a little-studied phenomenon.

The church on the territory of Western Ukraine has always been a place of general gathering of the community, accordingly, great importance was attached to the decoration of the church. At the end of the 19th and the beginning of the 20th centuries, the Art Nouveau style prevailed in architecture, which was formed in Europe in the 1880s. Given the fact that Galicia at that time was part of Austria-Hungary, it was the Austrian secession that was closest to the region under study and became the basis for the creation of the Ukrainian national style.

The iconography of Ukrainian monumental frescoes on the example of the church in the village of Nastasiv in the early twentieth century tends to revive the national tradition. Artists such as Damyan Horniatkevych, Andriy Nakonechny, Mykhailo Zoriy, Andriy Lepky, and Severyn Borachok aimed to combine individual style with traditional structure and content of polychromy, awakening national self-identification among the population and raising the level of its culture. Each of the mentioned artists tried to solve the tasks set in the time in his way. But they chose the path of expression, based on their vision of modernity while adhering to tradition.

Key words: sacred art, icon, murals, national traditions.

Постановка проблеми. Визначальною політичною ознакою галицьких земель кінця XIX століття стало бажання самовизначення на національному грунті, що мало безпосереднє відношення до ідей, які втілювалися у творчих роботах українських художників. Популяризація малярства Галичини кінця XIX століття пов'язувалася із християнськими храмами. Саме Українська Греко-Католицька Церква на чолі з митрополитом Андреєм Шептицьким стала рушійною силою національного духу, сформувала ідею самоусвідомлення себе як вільної та самостійної нації.

Аналіз досліджень. Незаповненою залишається сторінка історії західноукраїнського сакрального мистецтва кінця XIX століття, усіх складників процесу історичного та культурного розвитку, який відбувався на цих землях. Значна кількість наукових публікацій з'явилася наприкінці 1990-х на початку 2000-х років. Варто назвати сучасних українських дослідників, які писали про митців XIX - XX століття: Ю. Бірюльов (Мистецтво львівської сецесії), Д. Степовик (Історія української ікони X - XX століть), В. Щербаківський i Д. Щербаківський (Українське мистецтво: у двох томах з додатками), І. Гах (Західноукраїнський вітраж XX ст. Минуле, сучасне, майбутнє).

Мета статті - висвітлити процес становлення та розвитку сакрального монументального живопису в умовах творення українського національного стилю на теренах Східної Галичини у період між 1900-1940, проаналізувати творчість авторів сакрального мистецтва в середовищі храмів сучасної Тернопільської області на прикладі оздоблення церкви Вознесіння Господнього в селі Настасів.

Виклад основного матеріалу. Церква на території Західної України завжди була місцем загального збору громади, тому велике значення мало оздоблення храму. Вкінці XIX - на початку
XX століття в архітектурі панував стиль модерн, який сформувався в Європі у 1880-ті роки. 3 урахуванням того, що тогочасна Галичина входила до складу Австро-Угорщини, саме австрійська сецесія була найближчою для досліджуваного регіону і стала основою для творення українського національного стилю. Цей стиль проіснував у монументальному мистецтві Галичини до початку Другої світової війни. Національно свідома громадськість кінця XIX - першої половини XX століть ставила собі за мету створення українського національного стилю (Якимова, 2014: 105).

У західноукраїнській сакральній архітектурі вперше була здійснена спроба львівським архітектором Василем Нагірним (1848-1921 роки) на професійному рівні створити оригінальну форму української церкви. Прагнучи творити новий напрям, архітектор намагався поєднати різні стилі, беручи за основу візантійський. Стиль Василя Нагірного називають новітньою галицькою школою сакрального будівництва. Найціннішими є сільські церкви, які становлять більшість серед його творінь.

Однією з найкращих церков авторства Василя Нагірного вважається кам'яний храм у селі Настасів, що на Тернопільщині. УГКЦ Вознесіння Господнього спроектована в 1898 році у неовізантійському стилі, вона однобанна, хрестово-купольна у плані. Церква була освячена у 1902 році митрополитом Андреєм Шептицьким. Храм сприймається як цілісний синтетичний образ, в якому конструктивна деталь, живопис та інші елементи, зокрема інтер'єру, творять єдине ціле.

У перші десятиліття минулого століття завойовував позиції мистецький напрям «неовізантизм», започаткований Юліаном Панькевичем. Він засновувався на національній основі, а неодмінним атрибутом був народний колорит та 
орнаментика. Для цього, дбаючи про збереження традицій обряду, повернення до давньої структури сакрального стінопису, у 1932-1933-их роках були запрошені художники Краківської школи мистецтва Дам'ян Горняткевич, Андрій Наконечний, Михайло Зорій та Андрій Лепкий, які виконали поліхромію вівтаря. До оздоблення сакрального інтер'єру у 1937-1938 роках також долучився Северин Борачок.

У храмі села Настасів в апсиді святилища зберігся унікальний розпис художника-неовізантиста Андрія Наконечного, який народився 31 травня 1905 року на Тернопільщині в селі Урмань у заможній багатодітній сім'ї Михайла та Пелагії Наконечних. В 11 років Андрій став сиротою. Після закінчення початкової школи він продовжив навчання у приватній столярній майстерні Миколи Когута. Щоб прищепити своїм учням любов до мистецтва, майстер возив їх у музеї та на виставки до Львова.

У 1928 році майбутнього митця призвали на військову службу, де він служив на залізниці у Кракові як писар і оформлювач. Там молодий юнак тяжко захворів і його було відкликано від строкової військової служби. 3 дозволу старшин Андрій Наконечний залишився жити в казармі та одержав можливість брати уроки малювання у приватній школі професора Гофмана, а у 1929-1933 роках продовжив навчання у школі Альфреда Терлецького при Краківській Академії Красних Мистецтв. Любов до традиційного візантійського іконопису молодому митцеві прищепив професор Краківської Академії Кароль Гомоляш. Релігійний живопис став головним у його малярстві. За створення власного стилю його почали називати «українським Леонардо» (Музичук, 2011).

У творчості Андрія Наконечного значну роль відіграв Митрополит Андрей Шептицький, який замовляв у на той час маловідомого художника роботи, що дало змогу таланту майбутнього українського митця-неовізантиста розкритися. У 1938-1939 роках Андрій Наконечний на замовлення Митрополита Шептицького почав копіювати фрески з каплиці Чесного Хреста в резиденції польських королів у Вавелі. Копії фресок використовувалися Митрополитом Шептицьким як зразки візантійського ортодоксального малярства в іконописній школі, яка діяла при монастирі Студитів у Львові. Після приходу радянської влади в західні області України копії фресок, як і багато інших сакральних творів митця, зникли безвісти (Музичук, 2011).

Ескізи Андрія Наконечного для Настасівського храму нині зберігаються в Тернопільському обласному краєзнавчому музеї. Художник разом із Дам'яном Горняткевичем, Михайлом Зорієм та
Андрієм Лепким почав настінні розписи церкви з вівтарної частини, де в апсиді святилища зобразив композицію Вознесіння Господнього.

Монументальний живопис Вознесіння (рис. 1) поділений на дві частини: земну, на якій бачимо 11 апостолів і посередині Богородицю у побожній молитві 3 двома ангелами, які вказівними пальцями вказують на Ісуса Христа; та небесну, на якій зображено Христа в Славі, довкола якого чотири серафими і ангел біля підніжжя хмари, на якій він сидить. Ісус одягнений у золото-багряну одіж, на ньому вже не синя туніка (символ прийнятої людської природи), а золотиста тканина, яка додає слави і акцентує увагу на преображенні; він ніби прокладає міст між світом людей, який втілюють апостоли внизу, на землі, і світом Бога, де Він нас очікує та благословляє правою рукою. Варто зазначити, що Київська іконописна традиція канонічно зображала Спасителя, який благословляв обома руками тих, хто залишилися «внизу», або тримав згорнутий сувій у лівій руці. У зображенні композиції з села Настасів Ісус у лівій руці підтримує знизу та притискає до грудей символ влади - кулю.

Навколо голови Спасителя - хрещатий німб, який нагадує про смерть Спасителя на хресті. Починаючи з XI століття, у трьох видимих сторонах хреста німба пишуться букви грецького алфавіту $́$ (омега) - зліва «от», О̆ (омікрон) - вгорі «он», N (ню) - справа «наш», що означає «Сущий» і підкреслює Божество Ісуса Христа. У композиції настінного розпису церкви в селі Настасів букви закомпоновані по центру арки в медальйон, обрамлений рослинним орнаментом, і розміщені над головою Ісуса Христа. В орнаменті переважають жовто-сині кольори, що свідчить про використання кольорової гами, притаманної українській національній колористиці, стилізована метрична квіткова композиція складена у вигляді горизонтального серця, що надає урочистого завершеного обрамлення настінному розпису.

У розписі куполу церкви Вознесіння Господнього (рис. 2), ймовірно, брав участь Андрій Наконечний. У ньому зображена композиція коронування Діви Марії, яка є однією з найбільш поширених тем іконопису в Галичині. Коронування Діви Марії, Цариці Небесної, самим Богом згідно 3 доктриною Римо-Католицької Церкви $€$ одним з епізодів, який входить до циклу Вознесіння Богородиці (Руско, 2015; 150). Центральною постаттю монументального розпису є Богородиця, яка сидить у хмарах між Отцем і Сином, які разом увінчують ії короною. Марія увінчується Святою Трійцею. У ногах Богородиці три ангели: 
два 3 правого боку, один - зліва. Ангели з боків означають присутність небесних легіонів. Кольорова гама - небесно-золота.

У вівтарній частині, святилищі церкви села Настасів на пілястрах по обидва боки ризниці i дияконника зображені Святі Великомученики Петро і Павло. У цей період в розписах храму брали участь майстри Михайло Зорій та Андрій Лепкий. Ймовірно, вони і $є$ авторами цих розписів. Така поліхромія відрізняється від розпису Вознесіння Господнього. Апостол Павло зображений із схрещеними на грудях руками, які тримають оголений меч, яким його стратили, і книгу, що вказує на нього як автора послань. У Великомученика темне волосся і довга борода. Привертає увагу скорботний погляд, пильно спрямований на глядача. Одягнений апостол Павло у вишневий гіматій поверх синього хітона, взутий у сандалії. Неприродньо великий розмір надає його постаті стійкості та твердості.

Апостол Петро (рис. 3) зображений із характерними атрибутами апостолів - книгою в руці, яка $€$ символом християнського вчення, та ключами - символом відпущення гріхів і правом відкривати двері в Царство Небесне, даним Господом своїм учням. Проповідник зображений чоловіком похилого віку, міцної статури 3 коротким сивим хвилястим волоссям, короткою бородою і грубуватими рисами обличчя. Одяг Апостола - охриста гіматія поверх синього хітона, взутий у сандалії.

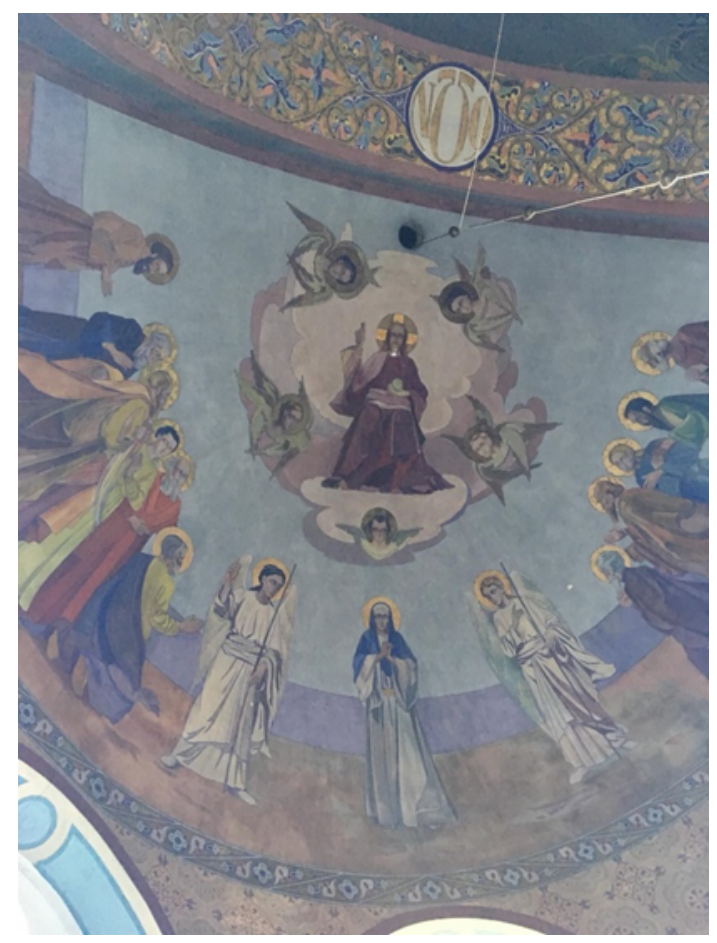

Рис. 1. Монументальний розпис в апсиді святилища у с. Настасів «Вознесіння Господнє»
На колонах у центральній наві зображені Українські святі: Ольга, Володимир, Андрій Первозванний і Григорій. Ці постаті змальовані уже в іншій стилістиці і пропорціях, ніж апостоли Петро та Павло, кольори розписів більш приглушені. Якщо святилище було розписане на початку 1930 -х років, то поліхромію храму, ймовірно, було виконано у 1937-1938 роках. Згідно архівних даних, які зберігаються в храмі УГКЦ Вознесіння Господнього, iii виконано художником Северином Борачком.

Народився майстер у селі Сороцьке Теребовлянського району Тернопільської області 22 червня 1898 року. Художню освіту митець здобув у Краківській Академії Красних Мистецтв протягом 1921-1924 років у відділі рисунків В. Яроцького. Мистецькі студії художник продовжував до 1937 року в Парижі, а у 1947 році виїхав до Мюнхена. Після виставки своїх творів у 1956 році у Нью-Йорку Северин Бурачок залишився на постійне проживання у США. Помер 8 липня 1975 року в місті Річмонд штат Вірджинія, США (Головчанська, 2004: 63).

У радянські часи церква в селі Настасів діяла як православна. Уряд СРСР прагнув знищити так звані «національні церкви», особливих гонінь зазнала Українська Греко-Католицька Церква. Багато настінних розписів, які не вписувалися в ідеологію Російської Православної Церкви, перемальовувалися або знищувалися. Якщо придивитися пильніше до зображення святого Григорія,

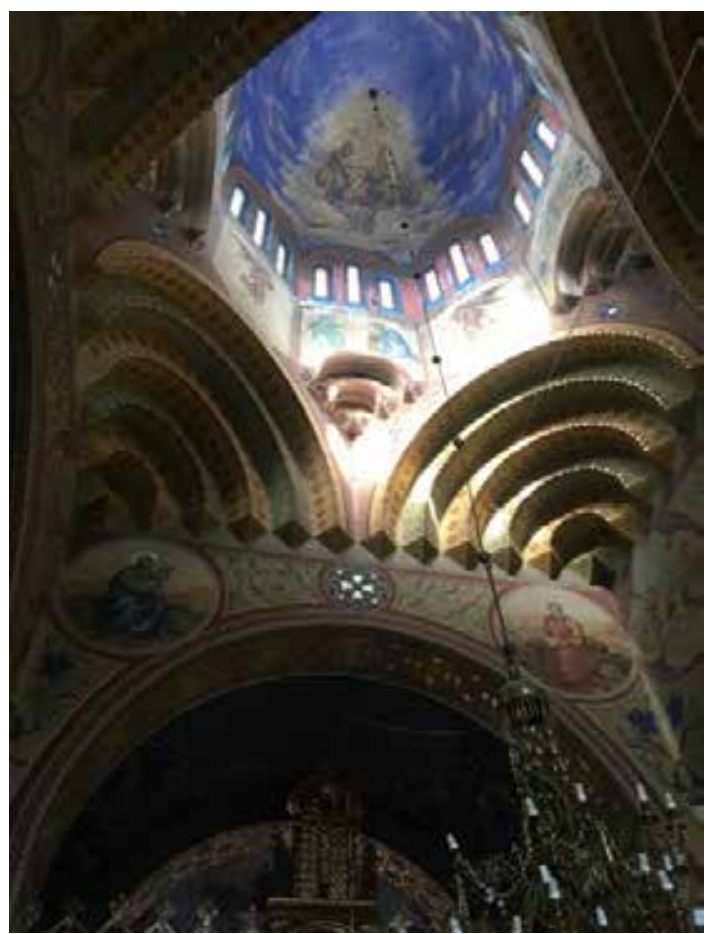

Рис. 2. Фрагмент розпису куполу у с. Настасів 


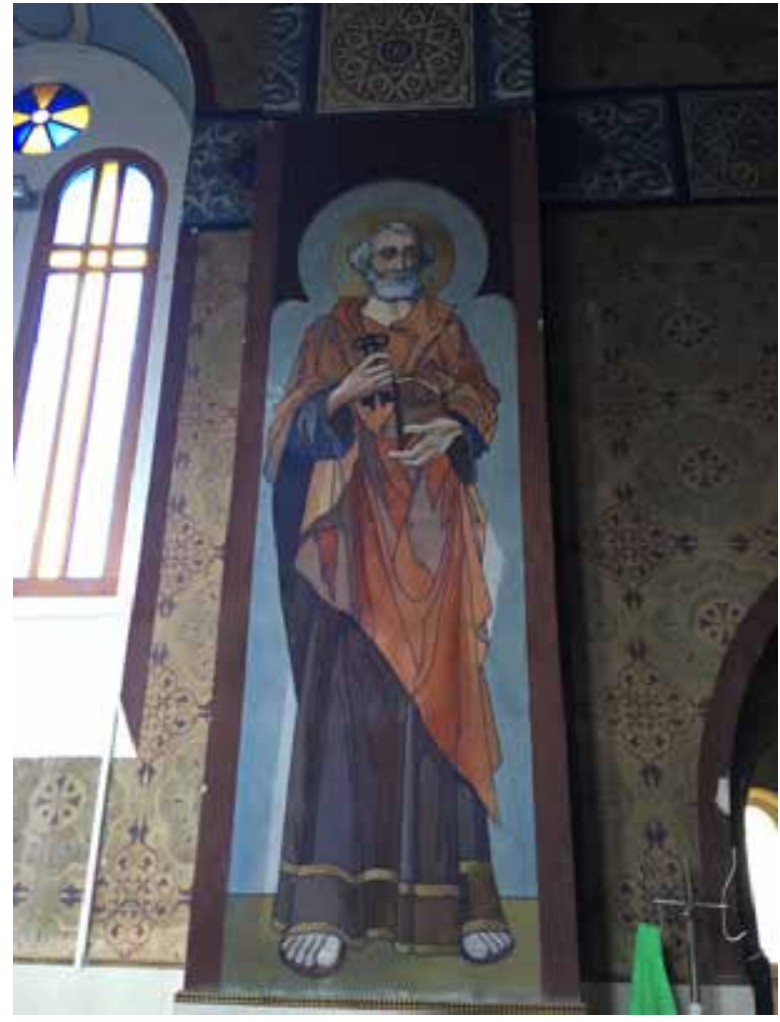

Рис. 3. Апостол Петро, церква с. Настасів

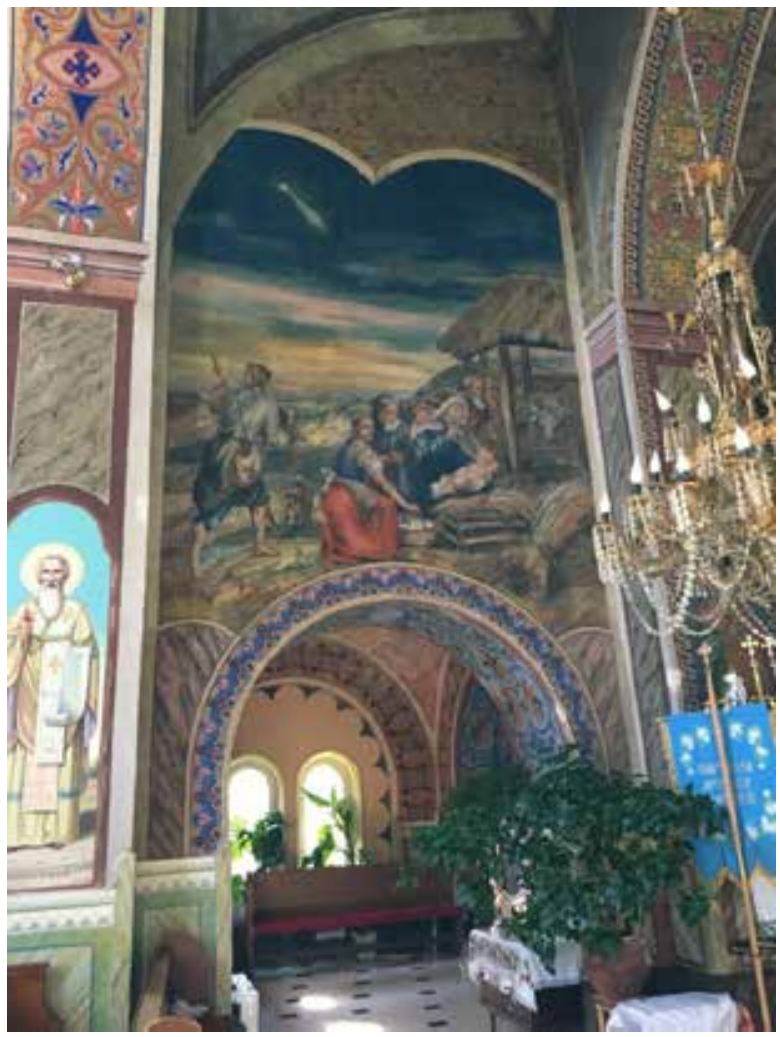

Рис. 5. Монументальний розпис «Різдво Христове», церква в с. Настасів

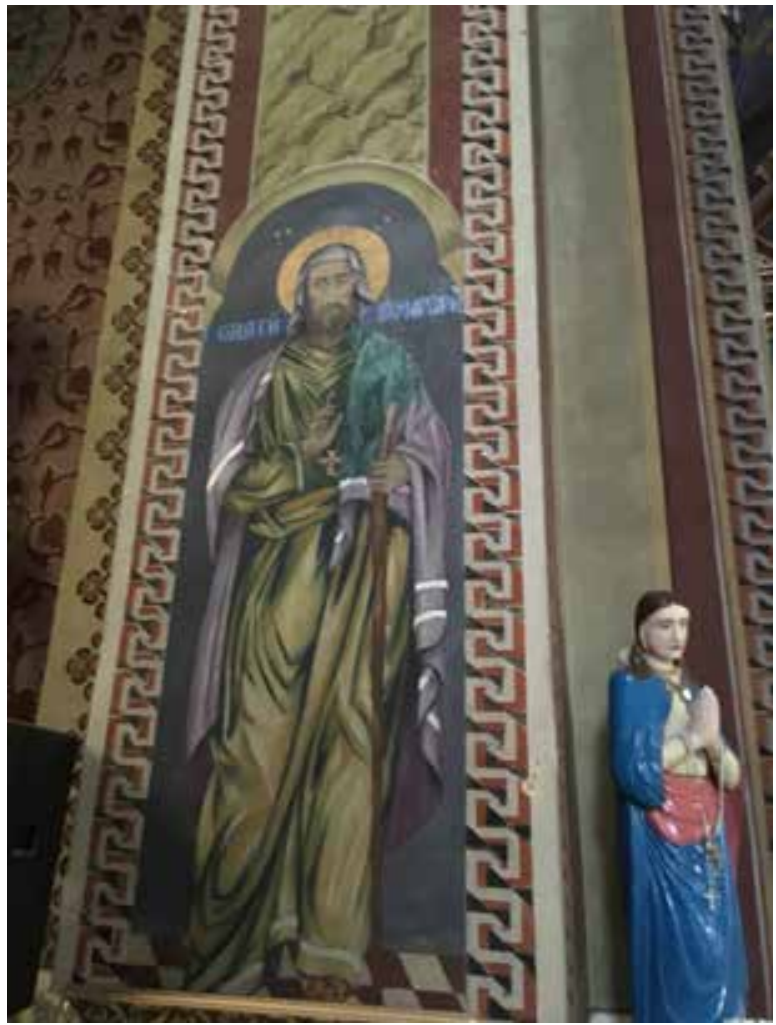

Рис. 4. Святий священномученик Йосафат Концевич, церква с. Настасів

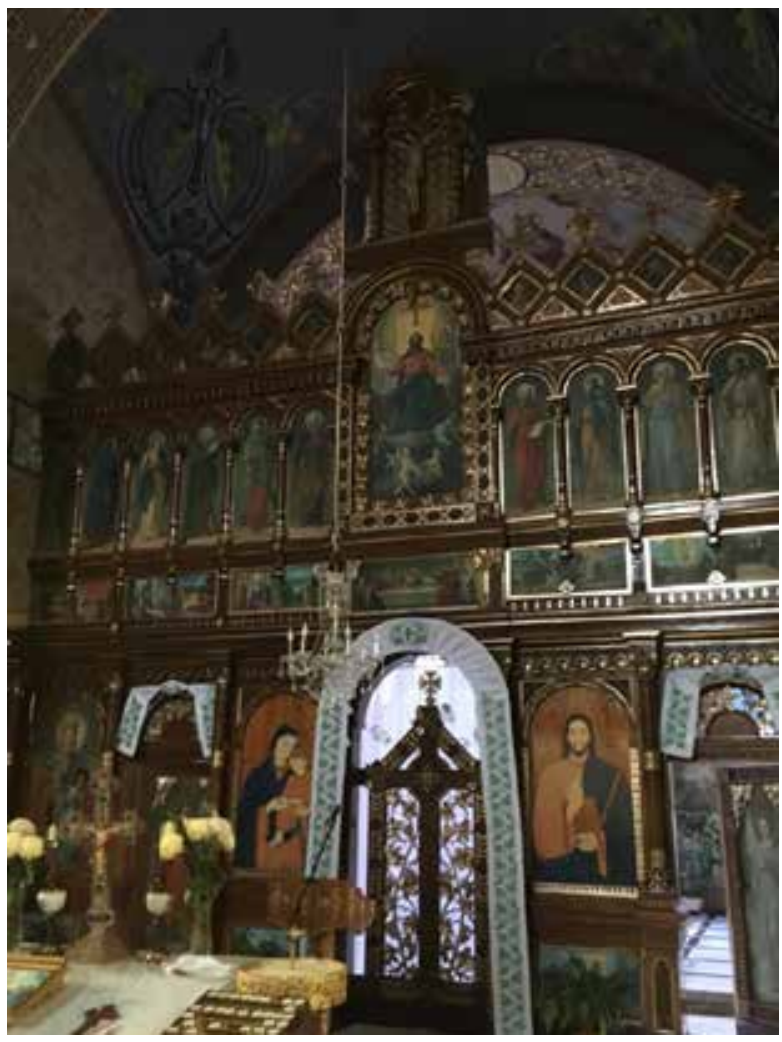

Рис. 6. Фрагмент іконостасу церкви в с. Настасів 
то побачимо, що на плечі святого проглядається темна пляма на фіолетовій гіматії у вигляді металевої частини сокири. Про що говорить цей факт?

У 2018 році Тернопільсько-Зборівська архиєпархія УГКЦ на чолі з доктором богослов'я отцем Віталієм Козаком випустила церковний календар із фотозйомкою у храмі в селі Настасів. Отець Віталій 3 достовірністю припустив, що зображення Святого Григорія малоймовірне, адже на колонах представлені українські святі. За концепцією доктора богослов'я, це була постать святого священномученика Йосафата Концевича (рис. 4), який зображався з сокирою, оскільки мав відрубану голову. Тому можна припустити, що священники МПЦ, які не визнавали священномученика Йосафата святим, і замалювали надпис і сокиру.

У храмі села Настасів цікавим є монументальний розпис Різдва Христового (рис. 5) у центральній наві, виконаний Северином Борачком у невізантійському стилі, для якого характерне використання в іконописі національних мотивів. Художник використав рівновагу кольорових мас, елементи української вишивки та одягу, геометричні орнаменти. У центрі композиції Різдва Христового зображено новонародженого Ісуса 3 Пресвятою Богородицею, яка підтримує його лівою рукою, а праву руку вона приклала до серця, уся іiї увага прикута до Христа.

Діва Марія та Ісус знаходяться в оточенні Йосифа, який праву руку тримає на плечі Богородиці, а у лівій тримає дерев'яний посох, погляд його збентежений, спрямований вдалечінь; 3 правого боку від Марії бачимо двох жінок: старшу, яка дивиться на новонародженого у білих одежах, та молоду в українському вбранні, яка опустилася перед Христом на коліно, ії голова повернута до вірян, а вказівним пальцем лівої руки вона вказує на дитятко. Позаду жінок постать пастуха, зображеного повернутим спиною до глядача, погляд його спрямований удалечінь, немов оглядається за кимось. Він зображений із ягням на руках, яке $є$ символом Агнця Божого - Ісуса Христа. У правому кутку композиції на передньому плані перед яслами зображено сніп пшениці, на задньому плані видніється вілпіддерев' яним навісом і солом'яною стріхою. Над усією композицією сяє зірка, довгий промінь якої показує на сцену народження немовляти. За допомогою іконопису автор впроваджує сюжет Різдва до буденної людської реальності.

Аналізуючи колорит розписів Різдва Христового, зауважимо, що небо і гірський пейзаж на задньому плані та центральна композиція виконані у жовто-синій гамі з відтінками зеленого та охристо-коричневого, тільки спідниця дівчини в українському вбранні активно виділяється, що $\epsilon$ композиційним акцентом автора для концентрації уваги глядача на зображенні сюжету. Перебуваючи в Парижі у 1930-х роках, Северин Борачок працював в імпресіоністичній манері. Сніп пшениці на передньому плані композиції з розмитою, нечіткою формою і маленькими мазками пензля вказує на елементи імпресіонізму у цьому монументальному розписі. Вся композиція Різдва Христового виглядає динамічно та цілісно.

У кутах примикання підпружних арок бані зображені євангелісти у круглих медальйонах i їх геральдичні символи у чотирипелюсткових розетках: Матвій та ангел, який представив людську природу Спасителя; Марко та летючий лев, адже він на початку Свангелія описує пустелю та Іоанна Хрестителя; Лука - автор третього Свангелія, який не був свідком подій, які описував, а володів талантом історика, тому образ Ісуса Христа в євангеліста відрізняється від Свангелія Матвія та Іоанна. Його зображено із символом вола. Як земна тварина повсякденно несе свої страждання, такий тягар мук переніс і Спаситель заради спасіння людства, оскільки віл у стародавньому світі був символом мучеництва. Апостол Іоанн вважається автором четвертого канонічного Євангелія, його геральдичний знак - орел, який символізує піднесення його віри.

Особливістю оздоблення церкви Вознесіння Господнього в селі Настасів є збережені круглі вітражі Дам'яна Горняткевича, який у 1932 році брав участь у розписах храму разом із колегами Андрієм Наконечним, Андрієм Лепким і Михайлом Зорієм. Дам'ян Горняткевич народився 13 листопада 1892 року в м. Ліську Сяноцького повіту. До кінця жовтня 1918 року він був солдатом австроугорської армії і одночасно студентом Краківської академії мистецтв. У 1924-1925 роках навчався у Дрезденській та Мюнхенській академіях мистецтв, пізніше працював у Львові. У 1930-х роках займався вивченням фресок у церквах Кракова, Любліна, Віслиці, Сандомира (Гах, 2017: 47).

Використання вітражів в оздобленні інтер'єрів українських церков - це запозичення із католицьких храмів, яке стало можливим завдяки специфіці української християнської церкви в Галичині. Дам'ян Горняткевич належить до тієї нечисленної когорти українських художників першої половини XX століття, які займалися проектуванням вітражів. Масове захоплення кольоровими вікнами наприкінці XIX - на початку XX століття, яке відбувалося у країнах Європи, призвело до повернення та творчого переосмислення цього виду монументального мистецтва (Гах, 2017: 47). Вікна 
доповнювали загальну образно-художню структуру внутрішнього оздоблення храму, але мали й дещо інше призначення - максимально заповнювати інтер'єр церкви денним світлом.

Дам'ян Горняткевич цікавився монументальним мистецтвом і не міг оминути увагою вітраж. Ще будучи студентом, він брав активну участь у реставраційних роботах, які проводилися в Маріяцькому костелі. Реставраційно-пізнавальна праця допомогла йому ознайомитися із класичними вітражами Маріацького храму зламу XIX - XX століть, які були створені відомими польськими художниками, викладачами Краківської академії Яном Матейком, Станіславом Виспянським і Юзефом Мехоффером. На прикладі цієї архітектурної споруди Горняткевич мав можливість ознайомитися із середньовічним і сучасним вітражами, спроектованими викладачами мистецького закладу (Гах, 2017: 48).

В інтер'єрі церкви Вознесіння Господнього було спроектовано чотири вікна круглої форми. На думку Ірини Гах, вітражі, якими заповнені вікна Настасівської церкви, були творчою ініціативою Дам'яна Горняткевича. Три яскраві «палаючі» хрести, які знаходяться у вікнах центральної частини храму, є виразною світловою домінантою інтер'єру і влучно доповнюють стінопис церкви. Трилисне закінчення ремен хрестів зумовлено теологічним трактуванням символів Христа і Трійці. Художником було впроваджене потрійне листя конюшини, яке завершує рамена хреста і за церковними канонами також використовується для позначення Воскресіння Христового (Гах, 2017: 48).

Іконостас церкви Вознесіння Господнього (рис. 6) та бічні престоли - дерев'яні з різьбою, іконостас п'ятирядний: перший - зображення Старозавітних сцен, другий - чотири намісні ікони: Ісус Христос із Свангелієм у руках, Богородиця 3 малим Ісусом, святий Іван Хреститель і святий Миколай. На бічних дверях - архангел Гавриїл та архангел Михаїл, центральні царські врата - різьблені, в основі орнаменту - закручені пагони, стилізоване листя, дрібні грона винограду. Третій ряд іконостасу займають ікони Святкового чину із демонстрацією 12 найголовніших свят, над царськими вратами розміщена ікона Таємної вечері. Четвертий ряд - Апостольський, у центрі ряду - Христос Пантократор. П'ятий ряд - Пророцький чин, в якому представлені пророки. Вся композиція увінчана скульптурою розп'яття Ісуса Хреста.

Ікони Ісуса Христа та Богородиці з намісного ряду відрізняються за стилістикою написання від усіх ікон в іконостасі. За словами настоятеля церкви отця Романа Габрилея, у 2017 році хмельницькі реставратори проводили хімічну обробку деревини іконостасу від жука-короїда і зробили припущення, що намісні ікони Iсуса та Богородиці виконані художником Модестом Сосенком на запрошення Андрея Шептицького. 3 невідомих причин він не зміг завершити розпочату роботу, тому інші майстри завершили оформлення іконостасу. Це припущення нічим не підтверджене і потребує дослідження.

Висновки. Підсумовуючи зазначене вище, можна констатувати, що іконографія українських монументальних стінописів Східної Галичини кінця XIX - початку XX століття тяжіє до відродження національної традиції, на що впливає спрямованість українського мистецтва першої половини XX століття. Кожен із згаданих митців ставив собі за мету поєднання індивідуального стилю 3 традиційною структурою та змістовим наповненням поліхромії, пробудження національної самоідентифікації серед населення та підвищення рівня його культури. Можна стверджувати, що сакральне монументальне мистецтво Східної Галичини першої половини XX століття посприяло творенню українського національного стилю.

\section{СПИСОК ВИКОРИСТАНИХ ДЖЕРЕЛ}

1. Бірюльов Ю. О. Мистецтво львівської сецесії. Львів : Центр Європи, 2005. 184 с., 385 іл.

2. Гах І. Західноукраїнський вітраж ХХ ст. Минуле, сучасне, майбутнє. «Манускрипт-Львів», 2017. 66 с.

3. Головчанська О. Повернуті імена. Маловідомий Северин Борачок. Вісник Прикарпатського університету. Серія: Мистещтвознавство. Випуск VII. Івано-Франківськ : «Плай». 2004. С. 63-70.

4. Музичук Н. Андрій Наконечний - художник-патріот. [Електронний ресурс]. http://hromada.hu/2011/nom_116/ ukrznavstvo/nakonecsnyj.html.

5. Руско Н. Особливості галицького іконопису кінця XIX - початку XX століть. Філософсько-релігієзнавчий контекст. Дисертація на здобуття наукового ступеня кандидата філософських наук. Острог, 2015. 197 с.

6. Степовик Д. Історія української ікони X - ХХ століть. 3-тє вид., стереотип. К. : Либідь, 2008. 440 с.; іл.

7. Щербаківський В. М., Щербаківський Д. М. Українське мистецтво: у двох томах з додатками; упоряд. О. О. Савчук. Харків : Видавець Савчук О. О., 2015. 472 с.

8. Якимова О. Процес творення українського стилю на території східної Галичини у першій половині ХХ ст.: ключові персоналії. Вісник ХДАДМ. 2014. № 2. С. 104-108. 


\section{REFERENCES}

1. Biruliov Yu. Mystetstvo lvivskoi setsesii. [The art of Lviv secession]. Lviv : Tsentr Europy, 2005. P. 184, I'll. 385 (in Ukrainian).

2. Hakh I. Zakhidnoukrainskyi Vitrazh XX st. mynule, suchasne, maibutnie. [Western Ukrainian stained glass of the twentieth century. Past, present, future]. Manuskrypt-Lviv. 2017. P. 66 (in Ukrainian).

3. Holovchanska O. Povernuti imena. Malovidomyi Several Borachok. [Returned names. Little-known Severin Borachok Visnyk]. Prykarpatskoho universytetu. Seria: Mystetstvoznavstvo. Ivano-Frankivsk : "Plai". 2004. P. $63-70$ (in Ukrainian).

4. Muzychuk N. Andriy Nakonechnyi - khudozhnyk-patriot. [Andriy Nakonechny is a patriotic artist]. Electronic resource. http://hromada.hu/2011/nom_116/ukrznavstvo/nakonecsnyj.html (in Ukrainian).

5. Rusko N. Osoblyvosti halytskoho ikonopysu kintsia XIX - pochatku XX stolit. [Filisofsko-religieznavchyi kontekst. Features of Galician iconography of the late XIX - early XX centuries. Philosophical and religious context]. Dysertatsia na zdobuttia naukuvuhu stupenia kandudata filosofsykh nauk. Ostroh, 2015. P. 197 (in Ukrainian).

6. Stepovuk D. Istoria ukrainskoi ikony. [History of the Ukrainian icon of the X - XX centuries]. 3 vud. Stereotyp. K. : Lybid. 2008. P. 440 (in Ukrainian).

7. Shcherbakivskyi V. M., Shcherbakivskyi D. M. Ukrainske mystetstvo: v dvoh tomah z dodatkamy. [Ukrainian Art: in two volumes with appendices]. Kharkiv : Publisher Savchuk O. O. 2015, P. 472 (in Ukrainian).

8. Yakymova O. Protses tvorennia ukrainskoho styliu na terytorii skhidnoi Halychyny u pershii polovyni. Kliuchovi personalii. [The process of creating the Ukrainian style in the territory of eastern Galicia in the first half of the twentieth century. Key personalities]. Visnyk HDADM. 2014. P. 104-108 (in Ukrainian). 